\title{
SOME REMARKS ON THE SOCIAL AND PRO- FESSIONAL STATUS OF PHYSICIANS AND SURGEONS IN THE IBERIAN WORLD, 16th-18th CENTURIES $(*)$.
}

\author{
C. R. BOXER \\ Professor da Universidade de Londres.
}

These cursory remarks, which do not pretend to do more than briefly discuss some aspects of this topic, will deal mainly with Portugal and her overseas possessions, since I assume that this angle will be less familiar to you than the Spanish and Spanish-American.

Medieval Portuguese physicians and surgeons were not allowed to practice until they had been examined by a qualified physician or surgeon, as the case might be, and issued with a licence to do so. The issue of such licences goes back to 1338 , at least, but the regulations were apparently ill obeyed, and steps were taken to strengthen them in the reign of Dom Afonso V. A royal decree of the 20 March 1443 ordered that all Jewish physicians and surgeons should be re-examined, with the exception of certain named individuals of proved skill and competence. All others would have their existing licences destroyed and they themselves would have to be re-examined at the Court by Mestre Aires and Mestre Martinho, respectively Físico-Mór and Cirurgiâa-Mór. Successful candidates would be given new and valid licences, while those who neglected to appear for re-examination would be severely punished (1).

Despite the peremptory tone of this edict, unauthorised practitioners evidently continued to flourish. At any rate, the royal Regi-

(*) $^{*}$ - Texto apenas lido perante uma audiência de hispano-americanos e norte-americanos por ocasião de um Congresso Médico na cidade de Antígua (Guatemala), em março de 1973. (Nota da Redação).

(1). - Iria Gonçalves, "Físicos e cirurgióes quatrocentistas: as cartas de exame", an excellent and well-documented article in Do Tempo e da História, Vol. I (Lisboa, 1965), pp. 69-112. 
mento of 25 October 1448, appointing a certain Mestre Gil as Cirurgiäo-Mór, authorised him to issue certificates of proficiency (cartas de exame) to such candidates as he had tested and found to possess adequate surgical knowledge and skill. These cartas de exame were to be acknowledged as valid by all magistrates, aldermen and other authorities, thus enabling their holders to practice surgery wherever they chose in the Kings's dominions. The Cirurgião-Mór was also given the privilege of being accompanied by three armed men

$$
\text { "with whatever and how many weapons he may choose", }
$$

by day or night. He was also authorised to order anyone practising surgery to show his carta de exame on demand (2). The Físico-Mór enjoyed similar rights and privileges which were confirmed and amplified in the Regimento do Fisico-Mór, promulgated by Dom Manuel I in 1515 .

For centuries, these cartas de exame were the indispensable legal requisites for anyone wishing to practice medicine or surgery. Foreign certificates of proficiency were not officially recognized, although they often seem to have been accepted in practice, and those who had them were supposed to submit themselves for re-examination by the Físico-Mór or the Cirurgião-Mór at the Portuguese Court. The only exceptions to this rule, were graduates of the faculty of medicine at the University of Lisbon, re-established at Coimbra in the 16th century, who were authorised to practice anywhere in the Portuguese empire once they had obtained their diploma. The teaching at the University, which relatively few people could afford anyway, was purely theoretical, based on commentaries of the classical Greek and Arabic authors, such as Galen and Avicenna. Practice was obtained outside the University by accompanying a doctor or a surgeon on his rounds of private patients, or in the hospitals, for a period of two or three years.

62.5 percent of the fifteenth-century cartas de exame analysed by Iría Gonçalves were conceded to surgeons. Although surgeons were less highly considered socially than physicians, since their profession was regarded as essentially a manual one, there were more of them, as their training was quicker and less costly (3). Three centuries later, Dr. Antônio Ribeiro Sanches complained that in default of qualified physicians, medicine in the provinces and overseas dominions was often practised by half-educated surgeons with dire results

(2). - Manuel Gomes de Lima, Memorias Chronologicas e Criticas para a historia da Cirurgia Moderna (Porto, 1762), pp. 11-15, where the Regimento of 25 October 1448 is reproduced from a certified true copy made in 30 July 1632 .

(3). - Iria Gonçalves, "Físicos e Cirurgiões", p. 83. 
(4). There was a definite Jewish preponderance among the Portuguese physicians and surgeons in the late Middle Ages, some 63.5 per cent of the cartas de exame being issued in favour of Jews. After the expulsion or forcible conversion of the Jews in 1497, the "NewChristians" or Christãos-Novos into which they were metamorphosed, continued to supply large numbers of physicians, surgeons, and apothecaries, despite periodic enactments limiting such professions to "Old Christians". This real or alleged suspicion of Judaism likewise contributed to lowering the prestige of the medical and surgical professions in the eyes of the public. In the late Middle Ages and during the sixteenth-century some women were licenced to practice as surgeons or barber-surgeons, and there may have been a few female physicians as well.

Although qualified physicians and surgeons never tired of denouncing the activities of quack-doctors, "wise women", and herbalists, these curandeiros of both sexes were often preferred by people of all classes, but especially those in rural areas. On at least one occasion, the povo or peoples representatives in the Cortes of 1472, spoke up in favour of the velhas and velhos

"que curavão com hervas e palavras Santas pelo amor de Deos" ("who cured with herbs and holy words for the love of God, doing much good to all there by"),

but who were often arrested at the instigation of the Fisico-Mór or the Cirurgião-Mór for practising without a licence (5). I may add that many of the nostrums and medicines prescribed by qualified physicians down to the end of the eighteenth century were often indistinguishable from those prescribed by the practitioners of folk-medicine, as can be seen from the Erario Mineral of Luís Gomes Ferreira (1735 and $1755)$, although this Luso-Brazilian surgeon was one of the fiercest opponents of curandeiros (6). One reason for the long continued po-

(4). - Antônio Nunes Ribeiro Sanches, Obras (ed. Coimbra University Press, 2 vols., Coimbra, 1963-66), Vol. II, pp. 49-50.

(5). - Iria Gonçalves, "Físicos e Cirurgiões", pp. 76-77. Cf. also A. H. de Oliveira Marques, Daily Life in Portugal in the late Middle Ages. (University of Wisconsin Press, 1971), pp. 136-53, "Hygiene and Health".

(6). - C. R. Boxer, "A rare Luso-Brazilian medical treatise and its author: Luís Gomes Ferreira and his Erario Mineral of 1735 and 1755", in The Indiana University Bookman, November 1969, Nr. 10, pp. 49-70. Cf. also, ibid., November 1973, Nr. 11, pp. 89-92, "A Footnote to Luís Gomes Ferreira, Erario Mineral, 1735 e 1755". Luís Gomes Ferreira received his Carta de Cirurgião on the 18 May 1705, after practising at the Hospital de Todos os Santos (Arquivo Nacional da Torre do Tombo, Lisboa, Chancellaria Real, Dom Pedro II, Livro 46, fl, 179). 
pularity of curandeiros in the Portuguese world was probably the fact that their folk-medicine did not involve the use of phlebotomy, on which most Portuguese physicians and surgeons relied to an extent which was noticed - and criticised - by all foreign visitors to Portugal and its overseas possessions.

A landmark in the history of Rortuguese medicine and surgery was the establishment of the great hospital of Todos os Santos at Lisbon. Founded in 1492, it was completed ten years later and given its Regimento by Dom Manuel I in 1504 . Badly damaged by fire in 1750 and by the earthquake of the I November 1755 , it continued to function on a makeshift basis until the staff and patients were transferred to the former Jesuit College of Santo Antão in April 1775, which was renamed the Hospital de São José. Surgical teaching began at Todos-os-Santos in 1502-04, and by 1515, the staff included one resident physician with a salary of 18.000 réis, and two surgeons, one resident with a salary of 12.000 réis, one non-resident at 6.000 réis, a resident apothecary with a salary of 15.000 réis, and a nonresident barber-bleender at 3.000 réis. The resident surgeon had to give a daily lecture to his two apprentice-pupils, who were each paid 2.000 réis, and who accompanied him on his rounds, thus combining theory with practice. In 1564, the Lisbon Santa Casa da Misericórdia took over the financing and administration of the Hospital; and a similar practice obtained in other Portuguese towns and cities, where a hospital was usually attached to or administered by the local Misericórdia (7).

The Hospital Regimento of 1504 carefully defined the functions of the physician, surgeon, and barbeiro-sangrador, the last named being quite distinct from and strictly subordinated to the other two, which was re-affirmed in the Regimento do oficio de sangrador, promulgated in 1572. Nevertheless, in practice there was much confusion and overlapping between surgeons, barbers, and bleeders, with barbeirossangradores often performing surgical functions, although this was forbidden by the law. A school of sangria was organized at Todos-os-Santos in 1620, but even after that the distinction between qualified surgeons, and barber-surgeons, or barber-bleeders was often blurred. For most of the public, barbeiro and sangrador were the same as cirurgião, and this inevitably affected the social prestige and status of the latter.

(7). - Sebastião Costa Santos, A Escola de Cirurgia do Hospital Real de Todos os Santos, 1565-1775 (Lisboa, 1925-28); Mário Carmona, $O$ Hospital Real de Todos-os-Santos da Cidade de Lisboa (Lisboa, 1954), for the above and what follows. 
The physicians were also careful to maintain their social and professional superiority to the surgeons. A chair of anatomy had been created at Coimbra in 1557, Afonso Rodrigues de Guevara being the first occupant. His teaching cannot have been very effective, as it was mainly based on Galen, with some notice taken of Vesalius' great work. After his departure, the standard of teaching declined still further, as neither autopsies nor dissections were carried out. Coimbra did not have a teaching hospital, nor practical medical or surgical courses, as did (to some extent at least) Salamanca and Guadalupe in Spain. Things were rather better at Todos-os-Santos, which was a teaching-hospital after a fashion, although it certainly had its ups and downs. The chair of anatomy at Todos-os-Santos had a longer life than that of Coimbra, but even it was suppressed altogether between 1739 and 1750 . At an earlier period, it was alleged in 1593 that any barber could get a certificate of surgical proficiency from the FísicoMór and the Cirurgião-Mór with the result that

\footnotetext{
"de maneira que não há dois cirurgiōes de que se possa fiar em todo o Reino" (8).
}

There can be no doubt but that the teaching and practice of medicine and surgery in Portugal lagged badly behind that of most Western European countries, including Spain, France, Italy, England, and the Netherlands. Anti-Jewish prejudice probably accounts for the fact that the most distinguished Portuguese physicians of the sixteenth-century, Garcia d'Orta, Amato Lusitano, Tomás Rodrigues da Veiga, and Zacuto Lusitano were not employed at Todos-os-Santos. A royal provisão of 1587 claimed that it was better to have one trustworthy "Old-Christian" physician (um só médico cristão-velho de confiança) than several New-Christian physicians on the staff, although in point of fact the number of beds had doubled since 1515. Luís Antônio Verney in his celebrated Verdadeiro Método de Estudar (1747), and Dr. Antônio Ribeiro Sanches in his Método para aprender e estudar a Medicina (1763), and his manuscript "Apontamentos para estabelecer-se hum Tribunal e Collegio de Medicina" (176?) made devestating and well-documented criticisms of the backward state of Portuguese medicine and surgery (9). Radical improvement only came about with the Pombaline reforms, partly inspired by Ri-

\footnotetext{
pp. 290-323.
} 290-323.

(8). - Mário Carmona, O Hospital Real de Todos-os-Santos, pp. 
beiro Sanches in these two aspects, and with the pioneer work of Manuel Constâncio (1726-1817). As Adrien Balbi noted in 1822:

On peut dire que la Chirurgie, avant Manuel Constâncio, n'etait pas cultivée en Portugal, puisque les chirurgiens portugais elevés dans le pays ne méritaient guère pour la plupart que le nom de barbiers, et qu' à l'exception des chirurgiens de la cour ils ne jouissaient d'aucune considération" (10).

Nevertheless the picture was not entirely black, and foreigners who were not favorvably impressed as a rule by Portugal and the Portuguese were sometimes frankly eulogistic in their accounts of the hospitals. An English Capuchin friar who spent some months at Lisbon in 1633, recounts in his diary how he was shown over the hospital of São Bartolomeu by a "religioso grave". This respectable priest assured his visitor that the hospital refused admission to none, irrespective of race, class, colour, or sex. When the Capuchin asked teasingly whether a Turk would be admitted, the priest retorted:

"y nos estava diziendo que alli se puede curar qualquier hombre o mujer del mundo sea de la nacion que fuere; yo pergunté si fuera un turco que? sea dize Turco, Moro, o Morisco sea lo que fuere, sea Castellano, ve alli todo dicho" (11).

Early in the eighteenth-century, the English envoy, John Methuen, who frequently found occasion to criticise the Portuguese, wrote to the Earl of Nottingham:

"I must do justice to the Portuguese, for certainly there never was better care taken of sick men in all the places, and there is on that account a great deal to acknowledge" (12).

As Balbi had noted, the only surgeons who enjoyed high social status and consideration were those attached to the royal court, of whom the Cirurgião-Mór was the chief. This was natural enough, as

(10) - Adrien Balbi, Essai Statistique sur le Royaume de Portugal et d'Algarve (2 vols., Paris, 1822), Vol. II, pp. 1xxij-lxxiv. For Manuel Constancio see Mário Carmona, O Hospital Real de Todos-os-Santos, pp. 313-323.

(11). - British Museum, Sloane Ms., 1572, f1. 58. This friar kept his diary in (a rather poor) Spanish.

(12). - John Methuen to the Earl of Nottingham, 22 April 1704 (Public Record Office, London, SP 89-18, Part I, fl. 90). I owe this reference to $\mathrm{Mr}$ John Villiers. 
reigning monarchs would obviously employ the best available physicians and surgeons for themselves and their families. Even so, their salaries were rather modest, as in the mideighteenth century the FisicoMór received an annual salary of $90 \$ 000$ and the Cirurgião-Mór one of $60 \$ 000$. By contrast, the royal anatomist in 1756 received $480 \$ 000$. Of course, they could supplement this with a private practice among the courtiers and nobility, as well as from the fees and emoluments they earned by issuing cartas de exame, etc. According to Gomes de Lima, it had become customary in Portugal to appoint a physician as Cirurgião-Mór, a practice which blighted the prospects of promotion for surgeons to the highest office, and further emphasized their subordination to physicians. This was likewise the rule in most other countries, including England down to the nineteenth century (13). French surgeons achieved full professional and social status with their medical colleagues in 1689, three years after Charles-François Félix, "premier chirurgien du Roi", had successfully operated on Louis XIV for an anal fistula (14). Royal gratitude had similar results in Portugal over half a century later. When Dom José I was wounded by a blunderbuss fired at his carriage when returning from a nocturnal assignation with his mistress, the young Marchioness of Tavora, he went to receive first-aid (and the sacraments) at the house of the surgeon, Antônio Soares Brandão. The treatment which he received then and later undoubtedly saved his life; so Soares Brandão was ennobled, and enjoyed great personal prestige and consideration as a result (15). Manuel Gomes de Lima in the flattering dedication of

(13). - The ancient union between the barbers and the surgeons was only dissolved by Act of Parliament in 1745. In the Royal Navy, the surgeon was still regarded as a craftsman rather than as a professional member of the gentry. Not until after the reform of 1805 could a naval surgeon be considered as "an officer and a gentleman". Keevil, Lloyd, and Coulter, Medicine and the Navy, 1200-1815, (3 vols., 1950-1961), Vol. III, p. 10.

(14). - P. Huard \& M. D. Grnek, La Cirurgie Moderne: ses débuts en occident, XVIe-XVIII siècles (Paris, 1968), p. 86. In 1689, the surgical College of St. Cosmé at Paris was given the right of teaching in Latin, which had hitherto been denied it, due to the opposition of the physicians. In 1731 there was created the Société Academique des Cirurgiens de Paris, which later became the Academie Royal de Cirurgie. In 1768 the College of Surgery in Paris was included in the Faculty of Medicine with equal rights, and in its own building.

(15). - Antônio Soares Brandão, son of a Minhoto surgeon of the same name, was born at São Pedro de Rubiães, near Viana do Castelo in 17?? He was a surgeon of the royal household in 1741, and later became Colonel in the army, "Cirurgiano-Mór do Reino e Senhorios de Portugal, e do Exercito, Fidalgo da Caza Real, Cirurgião da Real Camara, professo na Ordem de Christo, Provedor e Guarda-Mór de Saude do Porto de Belem", etc., etc. João da Matta, in his Tractado Cirurgico (Lisboa, 1763), dedicated to A. Soares Brandão, lauds him in the most effusive terms for his cure of Dom José, 
his Memorias (1762) to the (later) Marquis of Pombal, deliberately associated the latter with this upgrading or surgeons and their status:

"Up to the happy times of Your Excellency, the Portuguese surgeons found the doors shut on their further advancement. Their art suffered from being treated like a miserable step-daughter, and with no Father to protect it, met with the greatest discouragement on all sides. Thanks, however, to the greatness of Our Lord the King, and to the wisdom of Your Excellency, we now see worthy surgeons decorated with the highest privileges of the gentry (fidalguia), and a Professor as honoured as Antônio Soares Brandão placed in the position of Cirurgiäo-Mór do Reino" (16).

Even so, as noted above, full social and professional recognition for surgeons as the equals of physicians in Portugal came only in the days of Manuel Constâncio and with the founding of the Royal College of Surgery at Lisbon in 1825 .

It is natural that the professional and social status of physicians and surgeons in the Portuguese possessions overseas reflected to a large extent the situation in metropolitan Portugal. In "Golden Goa" (Goa Dourado) there was usually supposed to be a qualified FísicoMór and a Cirurgião-Mór, who would examine all candidates for practicing medicine and surgery (other than those with diplomas from the Faculty of Medicine at Coimbra) and issue them with cartas de exame. Sometimes the office was combined in one individual, and the same applied to the médicos (or cirurgiōes) de partido, the qualified physicians and/or surgeons who were licensed to practice in subsidiary settlements, such as Macao and Cochim, and who were engaged and paid by the local Senado da Camara or Municipal Council. Viceroys and Governors-General often brought their own private physician and surgeon with them, and they tended to appoint these men to the posts of Físico-Mór and Cirurgião-Mór during their three-year tenure of office, as an act of patronage. This procedure arroused considerable criticism, as the newcomers usually knew nothing about tropical diseases; and by the time they had learned, their patron's tenure of office was ended and they usually lost their own job.

which he claims had brought the Portuguese surgeon great fame abroad. (A. da Silva Carvalho, Medicos e Curandeiros, Lisboa, 1917, pp. 119-120). His Carta de Cirurgião, dated 13 January 1739, is in The Arquivo Nacional da Torre do Tombo, Lisboa, Chancellaria Real, D. João V, Livro 95, fls. 56-57.

(16). - Manuel Gomes de Lima, Memorias Chronologicas e Criticas (Porto, 1762), unpaginated dedication, and pp. 21-23 of text. 
The most famous Portuguese physician in India Portuguesa was undoubtedly Garcia d'Orta, author of the classic Colóquios dos simples $e$ drogas he cousas mediçinais da India, published at Goa in 1563 . Although physician to several successive viceroys and governors at Goa, where he built up a lucrative private practice between his arrival in 1534 and his death in 1568, Orta never became Físico-Mór do Estado da India, perhaps because of his Jewish origins (17). Orta lived at Goa during its figuratively golden years, when there were no major health problems apart from occasional outbreaks of cholera; but the city became notoriously and increasingly unhealthy after 1571, mainly because of endemic malaria and dysentery, and life for Europeans was usually short. This in turn meant that there was no longer any great inducement for Portuguese physicians and surgeons to seek their livelihood in erstwhile "Golden Goa". Great difficulty was experienced in filling the posts of Físico-Mór and Cirurgião-Mór. Sometimes they were unfilled for years on end; and in 1644 the Viceroy Count of Aveiras reported that the position of Fisico-Mór was held by a "Negro" (meaning, in all probability, a local Indian or Canarim) in default of a qualified white man. The Viceroy suggested that the Crown should send out some qualified physicians and surgeons, together with their wives, and a sufficiently attractive scale of pay to bind them to remain at Goa for the rest of their lives, instead of returning home with the Viceroy who had brought them out (18).

The Crown did not adopt this suggestion as a long-term policy, and complaints of the shortage of qualified white physicians and surgeons continued for many years. In 1688, the Governor-General reported that the then Físico-Mór, Dr. Simão de Azevedo, was a very old and tired man after serving many years in India, where he was the only surviving white doctor. He made his hospital rounds perfunctorily (de pé e de passagem) since he had to cope with an extensive private practice in the city and its suburbs, as well as between 100 and 200 patients in the hospital. He died two years later at the age of over eighty, and the Crown responded to the Governor-General's request by sending out two qualified physicians from Coimbra, with a contract to stay at Goa for eight years,

(17). - C. R. Boxer, Two Pioneers of Tropical Medicine: Garcia d'Orta and Nicolás Monardes (London, 1963), and the sources there quoted, the chief of which is Augusto da Silva Carvalho, Garcia d'Orta (Coimbra, 1934). (18). - Panduronga Pissurlencar (ed.), Assentos do Conselho do Estado da India, IV, 1659-1695, Goa-Bastorá, 1956, p. 578 n. 
"para que os discípulos fiquem com a capacidade necessária de lhes poderem suceder nas cadeiras".

A Cirurgião-Mór was also sent out with the same conditions (19).

The Royal Hospital at Goa, like that of Todos-os-Santos at Lisbon, experienced great vicissitudes over the centuries, but in its heyday it was regarded as being the finest in the world - such at least was the conviction of one of the patients there in the first decade of the 17th-century, the French sailor and traveller, François Pyrard de Laval. Pietro della Valle (1624) and Albert de Mandelslo (1639) also give very favourable accounts. The Hospital was originally financed by the Crown, and later administered by the Misericórdia and by the Jesuits at different times, with very conflicting evidence as to the results. The itinerant French Huguenot jeweller, Jean-Baptiste Tavernier, reported that the Hospital was still very well run on his first visit in 1646, but had declined badly by the occasion of his second twenty years later. The death-rate among the patients always seems to have been high, mainly because of the violent bleeding and purging treatment advocated by the physicians, whether Jesuits or laymen (20). Pyrard de Laval had observed that

"the system of medicine which they use is the same as in Spain, ... the continual fevers are cured by bleeding promptly, which they do continuously for as long as any trace of fever remains. The heathen Indians do not use bleeding".

Tavernier clearly approved of drastic bleeding as a cure for fever; but many of the old-timers at Goa, including several Viceroys and Governors-General, preferred the gentler methods of the local Hindu and Muslim healers and herbalists, whom the Portuguese termed panditos.

Many of the Portuguese-trained physicians denounced the panditos and all their works as being merely the Asian equivalents of the

(19). - A. C. Germano da Silva Correia, O Hospital Real de Goa nos séculos XVI e XVII (n. d. n. p. but Goa, c. 1950), pp. 84-87.

(20) - - A. C. Germano da Silva Correia ( $O$ Hospital Real de Goa, pp. 88-90) reproduces the integral text of a violent attack by the Fisico-Morr do Estado da India, Dr. José Henriques de Sequeira, on the Jesuit management (mismanagement according to him) of the Royal Hospital at Goa in 1730 . His accusations were backed by those of his colleague, the Cirurgião-Mór, José Dias Craveiro, but the Jesuit reply to these allegations has not been published, in so far as I know. 
curandeiros. But others were more cooperative, and Garcia d'Orta introduced a Hindu pandito into his Colóquios. In 1618, the municipal council at Goa promulgated a decree that

"no person of any religion, category, or nationality can exercise the medical or the surgical profession without passing a qualifying examination given by the Físico-Mor or the Cirurgiäo$-M o ́ r$, and they will be obliged to take out the certificate of examination",

those who who ventured to practice without them being fined twenty pardaos. The municipal council also decided that the number of Hindu physicians thus licensed to practice should be limited to thirty, and that the certificate of proficiency which they received from the Físico-Mór or the Cirurgiano-Mór, would have to be endorsed by the Camara as well, so as to ensure that the number of thirty should never be exceeded (21).

Much more might be said about the medical problem at Goa, but time does not permit. Turning briefly to Macao, (Cidade do Nome de Deus de Macao na China, to give the settlement in the estuary of the Pearl River its official name), we find that the first qualified European-trained physician to be appointed as médico e cirurgião de partido was a Frenchman from Landreçies in Flanders, Jacques-François Vandermonde, in March 1723. Ever since the foundation of the city in 1557 (or therabouts), there had been no qualified European physician or surgeon resident at Macao. Treatment was administered by a few ignorant barber-surgeons, or, more generally, by Jesuit-lay-brothers or by Franciscan friars who had acquired some empirical knowledge of the healing art. The lack of European specialists meant that most of the inhabitants relied on the expertise of Asian curandeiros, and that any quack could practice there. As a

(21). - Viriato A. C. R. de Albuquerque, O Senado de Goa. Memoria Historico-Archeologica (Nova Goa, 1909), pp. 423-25, "Posturas dos Fizicos, Cirurgiōes, Sangradores e Boticarios", d. Goa, 3 November 1618. João Manuel Pacheco de Figueiredo, "The practice of Indian Medicine in Goa during the Portuguese rule, 1510-1699", in The Luso Brazilian Review, Spring, 1967, pp. 51-60, publishes a number of these cartas de exame, d. 1613-1622, and cites a number of others. He assumes that these were licenses to practice Hindu medicinal methods but this is not explicitly stated in the text. On the one hand, the Portuguese Físico-Mór was not necessarily well acquainted with indigenous methods, and on the other hand the Hindu practitioners certainly had not been trained at Coimbra. These cartas de exame gave the holders permission to use the science of medicine in any part of the Portuguese empire (elle possa uzar siencia de fisiqa em todos os meus reinos $e$ senhorios onde se achar), which may, perhaps, imply that Western medicine rather than Eastern was meant. 
Jesuit lay-brother who acted as apothecary and amateur physician (much against in his own inclination and despite his admitted lack of any qualifications) explained in 1625:

\begin{abstract}
"donde vem que todas as parteiras chinas e canárias curam de medicina e de quantas enfermidades há, sem ninguem saber o que elas sabem. E como as mulheres dos portugueses, as mais delas, são chinesas ou têm parte disso, são mais afeiçoadas a este modo de cura, por ser o seu natural e, pelo contrário, extranham muito as curas ao modo português. De maravilha consentem que seus maridos façam uma cura perfeita ao nosso modo - como muitas vezes aconteceu - que, ordenando eu tal ou tal coisa ao enfermo, ou não the aplicam o que se the mandou fazer, ou acabam com ele que não o faça. Estando eu atualmente curando, ao presente, dois portugueses, sem minha ordem chamou-se a cada um deles a sua parteira, com as quais se curavam e por esta desordem se foram nara a outra vida".
\end{abstract}

Jacques-François Vandermonde was paid a salary of 500 patacas (Spanish-American pesos de ocho reales, or pieces-of-eight) yearly by the Senado da Câmara, on condition that he treated the poor free of charge, and that he would furnish his own medicine-chest and supply drugs and medicines at reasonable prices to wealthier patients. $\mathrm{He}$ had a chequered career in Macao (23), being highly praised by some of his patients, including the Jesuit Bishop of Peking, Polvcarp de Sousa, and denigrated by others. He was dismissed by the Municipal Council in July 1729 , partly on the grounds that he was a foreigner, and partly for his alleged misbehaviour with some of his female patients, including the Franciscan nuns or "Poor Clares". He had married a Macaonese girl and applied for Portuguese nationality, which was granted him by the Viceroy of Goa in 1733 . But since his wife had died shortly before this, he returned to France with his infant son, Charles-Augustin Vandermonde, who later became a distinguished surgeon at Paris and a minor figure of the Enlightenment before his premature death in 1762. A later and more satisfying incumbent of the position of Cirurgiano-Mór was the European-born Domingos José Gomes. He was a qualified surgeon by profession, but also practised medicine and traded profitably in opium. He co-

(22) . - Representation by the (anonymous) Jesuit lay-brother in charge of the botica at the Jesuit College of Madre de Deus, d. Macao 21 December 1625, apud Caetano Soares, Macau e a Assistência. Panorama Médico-Social (Lisboa, 1950), pp. 28-32.

(23). - Manuel Teixeira, Os Médicos em Macau, (Macau, 1967), pp. 7-11; and the Biographie Universelle entry under Ch. A. Vandermonde. 
operated with the famous Spanish medical and surgical luminary, Dr. Francisco Xavier Balmis, in the successful introduction of vaccination into Macao from the Philippines in 1805-06 (24).

Turning to the other side of the Portuguese empire, we may now glance at Bahia. The admirable work of John Russell-Wood, Fidalgos and Philanthropists. The Santa Casa da Misericórdia of Bahia, 15501755 (1968), has many references to physicians and surgeons. The Misericórdia employed a paid medical staff for the hospital, ranging from officially qualified doctors and surgeons to male nurses who had been promoted from carrying funeral biers. During the 17th century, one doctor and one surgeon were employed; but a second doctor was appointed in 1711 and two surgeons were maintained between 1732 and 1757. As was the case in metropolitan Portugal, and at Goa, Macao etc., these physicians and surgeons, as well as the pharmacist or apothecary in charge of the botica were all supposed to be Christãos Velhos or "Old Christians". The duties of the medical staff were to visit the hospital morning and evening, to be on call at any hour of the day or night if summoned to the hospital, and to treat the prisoners in the jail on the roll of the Brotherhood. A royal decree of 1585 had enacted that any physicain who was an Old Christian and who had received his medical training at Coimbra should be preferred over any other doctor. This ruling was reflected in the Compromisso or Statutes of the Misericórdia at Bahia. as it was in those of other Misericórdias in the Portuguese world (25).

The barbeiro-sangrador was usually a coloured person at Bahia, sometimes even a slave and often a Free Black, and perhaps with only rudimentary training in his art. In the mid-eighteenth century, the Municipal Council instituted (or revived?) examinations for all mecânicos plying their arts and crafts. The certificate of competence for a barbeiro-sangrador followed the Portuguese model

"que ele possa sangrar, sarjar, lançar ventosas e sanguessugas".

I may add that Portuguese warships and Indiamen were supposed to carry a qualified physician and a surgeon aboard, but in practice they rarely had more than one or two unskilled surgeons and bar-

(24). - Manuel Teixeira, Os Médicos em Macau, pp. 30-42.

(25) . - J. Russell-Wood, Fidalgos and Philanthropists, pp. 267, 278-80. A good survey of the field in general by Lycurgo Santos Filho, "Medicina colonial", in Sérgio Buarque de Holanda (ed.), História Geral da Civilização Brasileira, Tomo I, Vol. 2, (São Paulo, 1960), pp. 145-174. Cf. also Lourival Ribeiro, Medicina no Brasil Colonial (Rio de Janeiro, 1971). 
beiros-sangradores, and (in the late 17th and the 18th centuries) some male nurses belonging to the Hospital Order of São João de Deus. For example, the royal frigate which voyaged between Goa and Macao in 1709 had only a Cafre (Black African) barber-surgeon aboard, and this instance was probably far from untypical (26).

As happened at Macao, Goa and elsewhere in the Portuguese world, foreign physicians and surgeons were often employed in colonial Brazil, despite the laws against their being allowed to practice there. In 1717, for example, the Bahia Municipal Council wrote to Dom João V, asking that a French surgeon should be allowed to stay, despite a recent royal order to expel all foreigners from Bahia, because he had developed a successful remedy for the morbo gallico (27). Luís Gomes Ferreira in his Erario Mineral alludes favourably to some foreign surgeons who worked in Brazil in his time (17071731), including a Hungarian in Minas Gerais and a Frenchman in Pernambuco. These foreign physicians and surgeons were mostly French, as were those who worked in the Spanish-American empire in even greater numbers. Presumably the main reason for their employment, despite the existing laws prohibiting foreigners from residing in the Iberian colonies, was the great prestige enjoyed by the French medical and surgical schools, especially those of Paris and Montpellier. All these doctors, whether Portuguese or foreign, had to face active competition from the curandeiros, as they constantly complained; but since the remedies of folk-medicine were often less violent and painful than those employed by qualified practitioners, it is not surprising that the curandeiros continued to flourish, particularly since the great bulk of the population were too poor to afford ostensibly better qualified consultants.

If folk-medicine, largely derived from Amerindian elements, flourished in the sertões or backlands of colonial Brazil, it was even

(26). - When António de Albuquerque Coelho was wounded at Macao on 2 August 1709, "Recolheu-se neste Convento [de São Francisco] onde o Cirurgião da Cidade, Antonio da Silva, e hum Cafre Cirurgião da Fragata de Goa o curarão..." (Coleç̧ão de Varios Factos cited by Manuel Teixeira, Macau e a sua Diocese, VII, Padres da diocese de Macau (Macau, 1967), pp. 439-94). Cf. also António Marques Esparteiro, "A Higiene nas Naus de Viagem em meados do século XVIII", in the Boletim da Sociedade de Geografia de Lisboa (Outubro-Dezembro of 1958), pp. 279-296, especially p. 293, “... Costumão cada Nau trazer dous cirurgioens e dous sangradores ignorantes; porem já elevados com a Fidalguia da India desprezão fazer as barbas, cortar cabelos, e tirar dentes, dizendo que não hé isto de sua obrigação...".

(27). - J. Russell-Wood, Fidalgos and Philanthropists, p. 290. For the employment of foreign doctors by the Municipal Council at Macao see Arquivos de Macau, I (1929), p. 21; ibidem, $3^{\circ}$ series, Vol. 2 (1964), pp. 306, 378; Manuel Teixeira, Médicos em Macau, pp. 7-11, 13, 17-21, 42-43. 
more widespread in the Portuguese African possessions, not least in Angola, where Bantu influences predominated. In this traditionally "White Man's Grave", European doctors and surgeons were usually conspicuous by their absence, the colony being little more than a dumping-ground for convicts (degredados) and an entrepôt for the slavetrade. The official establishment included a Físico-Mór do Reino de Angola, but the post was often vacant for years on end, as the Câmara of Luanda repeatedly complained (28). Nevertheless, even in these highly unfavourable surroundings, medical science had its self-sacrificing devotees and made some progress. Dr. Francisco Guerra has drawn attention to the pioneer work on tropical diseases done by the Físico-Mór, Dr. Aleixo de Abreu, and published in 1623 after his return to Lisbon (29). More recently, Professor Luís de Pina has published a forgotten Treatise on the endemic diseases of Angola, compiled at Luanda in 1770 , by another Físico-Mór, Dr. Francisco Cosmé Damião. This qualified physician met with such strong opposition from the local curandeiros, that he had to take refuge in the governor's palace in order to preserve his life (30).

Turning to the Spanish world, the teaching and practice of both medicine and surgery in Spain was undoubtedly on a higher level than that in Portugal, particularly in the 16th-century. Moreover, whereas the whole Portuguese world had only one University where medicine was taught and where physicians could graduate, Spain had several, of which we need only recall Salamanca, Alcalá, and Seville, and others were established in Spanish America, including Mexico, Lima, Guatemala and Bogotá. The supply of qualified physicians and surgeons - for surgery and anatomy were taught at some of the Universities - was therefore better than for Portugal and its Empire, but some of the problems were common to both Iberian cultures. Physicians were usually more highly regarded socially and better paid than surgeons, whose educational standards were often lower, and barber-

(28). - C. R. Boxer, Portuguese Society in the Tropics. The Municipal Councils of Goa, Macao, Bahia, and Luanda, 1510-1800 (Madison, 1965), p. 136 .

(29). - Francisco Guerra, "Aleixo de Abreu, 1568-1630, Author of the earliest book on Tropical Medicine, describing Amoebiasis, Malaria, Typhoid Fever, Scurvy, Yellow Fever, Dracontiasis. Trichuriasis, and Tungiasis in 1623", reprinted from the Journal of Tropical Medicine and Hygiene, March 1968, Vol. 71, pp. 55-69.

(30). - "Tratado das Queixas Endémicas, e mais Fataes nesta Conquista", with an introduction and notes by Prof. Luís de Pina, in Studia. Revista Semestral, Vol. xx-xxii (Lisboa, 1967), pp. 119-268. Cf. also Manoel dos Anjos da Silva Rebelo, Relaçós entre Angola e Brasil, 1808-1830 (Lisboa, 1970), pp. 108-121. 
surgeons were regarded as being artisan or working-class rather than as professional men, just as they were elsewhere.

James Lockhart has sketched some of the succssful physicians in early colonial Perú, but he notes that a medical degree, although prestigious, did not carry the overwhelming weight of a degree in either canon or in civil law. He also notes that only one or two physicians ever received encomiendas, before 1560 , but evidently more of them did so afterwards (31). At any rate, a representation to the Crown which was considered by the Consejo de Indias at Madrid in 1607, claimed that many of the worthy descendants of the conquistadores in America were being passed over in favour of less deserving categories of persons, including (32).

"physicians, surgeons, notaries and other professional men"

This was a stock complaint and should not be taken too seriously; but it does indicate that chances of social advancement had improved for physicians and surgeons in early 17th-century Spanish America.

The Spanish Crown successively established Protomédicatos at important centres such as Mexico City, Lima, and La Habana, where candidates for medical and surgical degrees could present themselves for examination. If successful, they received certificates of proficiency allowing them to practice, if they had not already obtained such degrees at a Spanish University. However, this law was apparently often and easily evaded, judging by reiterated Cédulas Reales ordering it to be enforced; and sometimes the protomédicos gave certificates after the most cursory and farcical examination (33). For long periods the office of "Protomédico de las Provincias del Perú y Tierre Firme"

(31). - James Lockhart, Spanish Peru, 1532-1560. A Colonial Society, (University of Wisconsin Press, 1968), pp. 49-50, 60-61, 65-68.

(32). - “... y en muchas partes se ven con encomiendas médicos, cirujanos, escribanos y otros oficiales, no por sucesión de padres y abuelos, sino por provisiones hechas en ellos, sin servicios que lo merezcan, pues ni ayudaron a descubrir y ganar la tierra, ni la han pacificado...". Consulta of the 21 May 1607 in Richard Konetzke (ed.), Colección de Documentos para la Historia de la Formación Social de Hispanoamérica, 1493-1810, Vol. II, (1), 1593-1659 (Madrid, 1958), p. 130.

(33). - R. Konetzke, Colección de documentos, Vol. II, 1593-1690, pp. 263 (R. C. of 13 Sept. 1621); lbidem, pp. $785-87$ (Consulta of 26 August, 1686); Ibidem, op. cit. Vol. III, 1691-1807, p. 78 (R. C. of 31 December 1699); pp. 304-05 (R. C. of 22 December, 1761); pp. 383-85 (R. C. of 4 December 1771): pp. 597-601, (Dictamenes del Fisco del Consejo de Indias, 28 May and 9 ..ugust 1786). 
was attached to the Prime Chair of Medicine at the University of the City of Kings (Lima), but this arrangement did not always work smoothly, especially when the Chair was vacant, or occupied by a man of mediocre ability (34). The Protomédicato of la Habana was a sub-delegate of the one in Mexico City, and periodic efforts by the former to raise the status of its occupants to those of Mexico and Lima were sharply rebuffed by the Crown (35). A pragmatic promulgated in 1716 enjoined that only physicians and surgeons were allowed to ride on pacing mules (mulas de paso), all other people being allowed to ride only on horses and hacks (rocines) (36). A Crown ruling of 1769 exempted physicians, surgeons, and apothecaries from serving in the militia, but not their sons and servants (37). Among the qualifications essential for a protomédico was that he should be white, legitimate, and of Old-Christian descent with no doubt about his purity of blood (limpieza de sangre). The same social qualifications were apparently exacted of physicians; but in the second half of the eighteenth century (if not before) a number of coloured men (pardos) were allowed to practice surgery, and in due course medicine as well. When the Protomedicato of La Habana refused to admit a free pardo surgeon, Miguel Joseph de Aviles, to sit for a proficiency examination, simply on the grounds that he was a coloured man, the Crown ordered that body to do so, by a royal cédula of the 29 July 1763 (38). In 1765 the Governor of Cuba "provisionally" suspended all surgeons "who were clearly known as pardos" from practising their art in the city of la Habana; but he authorised them to continue to do so in the countryside and on haciendas

\footnotetext{
"donde hay crecido número de sirvientes esclavos y otras personas" (39).
}

There was, therefore, still some social discrimination against pardo surgeons; but in 1793 the Crown ruled that three pardo physicians (de calidad pardos y profesores de Medicina) should be admitted to the School of Anatomy recently founded at Caracas, and to which

(34). - R. Konetzke, Colección de documentos, Vol. II, pp. 785-87, and Vol. III, pp. 597-601.

(35). - R. Konetzke, Colección de documentos, Vol. III, 1691-1807, pp. 204-05 (R. C. of 11 May, 1731), p. 246 (R. C. of 23 May, 1750).

(36) . - R. Konetzke, Colección de documentos, Vol. III, p. 130 (Pragmatica of 10 February 1716).

(37). - R. Konetzke, Colección de documentos, Vol. III, p. 351 (Reglamiento of $19 \mathrm{Jan} .1769$ ).

(38). - R. Konetzke, Colección de documentos, Vol. III, pp. 315-16.

(39). - R. Konetzke, Colección de documentos, Vol. III, pp. 329-331. 
they had been refused admission (40). Some ten years later, a young pardo surgeon of Caracas applied for permission to marry a white orphan girl, Doña Maria del Carmen Correa, victim of a previous unfortunate-love affair. The girl was willing enough, and the couple became formally engaged, but $I$ have not been able to ascertain the final outcome of this romance (41).

Although there were evidently more and better qualified physicians and surgeons in Spanish America than there were in Brazil, there were still not enough to go around. This led to identical results in both empires, since not only did herbalists, quacks, and charlatans flourish, but, as Dr. Carlos Martinez Durán has noted in his classic Las Ciencias Medicas en Guatemala, Spanish America became the promised land for French physicians, surgeons, and dentists, especially in the eighteenth century. Some of them ended up in prison, others were deported after a longer or shorter period of time, but a number won acceptance, married, settled down and left descendants and pupils (42). Dr. Durán has also described in authoritative fashion the vicissitudes of medical science and its practitioners in Guatemala, more particularly since the foundation of the University of San Carlos with an endowed chair of medicine in 1681. Despite the good work done by certain individual doctors and surgeons under the most discouraging conditions, the numbers of graduates remained small for the whole of the colonial period. Only a total of twelve graduated between 1681 and 1773, the first of them in 1703. A College of Surgery attached to the University was opened in April 1805, but four years later none of the teaching staff had yet received a single real of their salaries, and it finally closed its doors in 1818. The reason for this state of affairs is indicated by Dr. Duran when he writes of the medical profession in colonial days:

"pues esta profesión nunca fue bien vista por la clase noble, $y$ aun en las otras clases sociales, no era preferida" (p. 239).

This observation can be applied, mutatis mutandis, to all the lberian world during the centuries we have briefly surveyed. It is all the more creditable that figures like Nicolás Monardes, Garcia d'Orta,

(40) . - R. Konetzke, Colección de documentos, Vol. III, pp. 719-20 (R. C. of 21 June 1793).

(41). - R. Konetzke, Colección de documentos, Vol. III, pp. 829-31 (consulta of 26 August 1806).

(42). - Carlos Martinez Durán, Las Ciencias Medicas en Guatemala. Origén y Evolución (3 ed., Guatemala, 1964), pp. 300-303, 355-57. 
Juan Fragoso, Don Manuel de Avalos y Porres, Dr. José Felipe Flores, Don Narciso Esparragoza y Gallardo, Aleixo de Abreu, Luís Gomes Ferreira, Antônio Soares Brandão and Manuel Constâncio were able to achieve as much as they did.

C. R. BOXER. Nasceu em 1904. Serviu no exército britânico de 1923 a 1947, sendo ferido em combate (dezembro de 1941) e prisioneiro dos japoneses. Professor catedrático da Cadeira de Camões na Universidade de Londres, de 1947-50 e 1953-67. Professor catedrático de História do Extremo-Oriente na mesma Universidade (1951-55). Professor catedrático da História da Expansão da Europa na Universidade de Yale (1969-1972). Membro da Academia Britânia desde 1957. Possui os graus de Ph. D e D. Litt. Professor Honoris Causa das Universidades de Utrecht (1950), Lisboa (1952), Bahia (1959), Liverpool (1966) e Hong-Kong (1971). Autor de, pelo menos, mais de 30 livros e 100 artigos. 